\title{
KALEIDOSCOPE
}

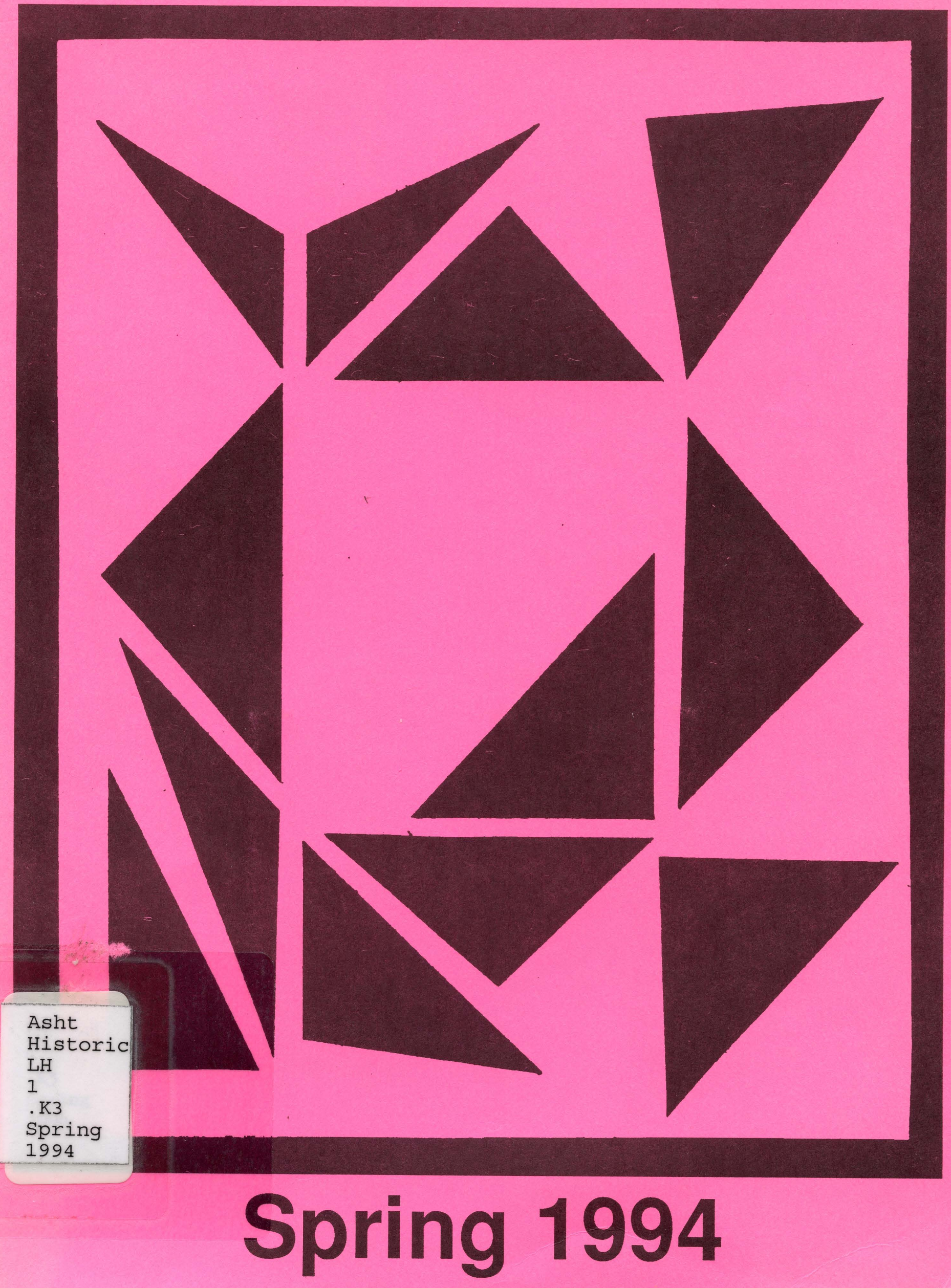




\title{
KALEIDOSCOPE
}

\author{
Spring 1994
}

\section{Kent Ashtabula}

A collection of

poems, essays, short stories, and artwork

by the students at Kent Ashtabula 


\section{Table of Contents}

Letter from the Dean

Letter from the Advisor.

Letter from the Editor

Kaleidoscope Winner's List

It Once Was A Grand Old House

Untitled

Spring Ahead.

Untitled

Fortress

Untitled

The Night The Tooth Fairy Fell Asleep on the Job

Untitled

Before

Untitled

Ode to the Great Hunter.

Untitled

Jenny.

The Hunt

Marshfolk

The Christmas Gift.

I

Mystery

Untitled

Harm's Way

I Want

Time.

Untitled

I Wonder

March 13, 1993.

Unidentified by: A schizophrenic Neurologist Mime

Fire In The Sea: Journal Entries of Christian Cooke, Cabin Boy.

Cumulus 
It is always a pleasure for me to append a short note to the Kaleidoscope. The production of this collection assures me that our students realize, in part at least, the meaning of one of the enigmas of the so-called "Information Age," in which data has mysteriously come to be synonymous with information. But data is not information, and information alone is not good prose, is not poetry, is not creative exposition, is not art.

Congratulations to prize winners.

Kudos to Editor, Gus Krage; to Editor Protem, Vern Johnson; to all the staff; to Advisor, Professor Hal Dalrymple; to the judges of this year's contest: Kelly Ingersoll, Tammy Wetherholt, Professors Roger Craik, Harry Izenour and Terry White; and especially to those who contributed their works --all winners.

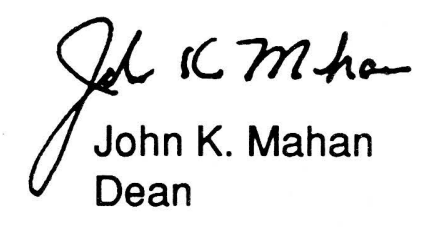




\section{From the Advisor}

Having to write this letter the last two years increases my respect for contributors to the Kaleidoscope and those who toil to bring the finished form to their fellow students. As I read this year's literature and viewed the art work, I was pleased to see new names, but I missed seeing the names of the contributors from last year, and I wondered where they are and what they are doing. Some are still on our campus and busy with other activities. Now, however, they are all as permanent a part of our campus' culture as anyone can be.

This lead me to remember The Kaleidoscope from twenty plus years ago at this campus. There is a wealth of shading to the color of the fabric of life available in the pages of this literary magazine over the years it has been published. Human feeling and its expression is a constant. The value, norms, behaviors and results of those behaviors have changed and changed again over those years. But so long as we can maintain The Kaliedoscope, we have a special, precious, and personal way of remembering time at Kent, Ashatabula. We have our staff, the contributors, and the Dean to thank for making the time mirror that is our Kaleidoscope possible. As ornate and nostalgic as this letter has become, the most tasteful thing for me, as advisor, to say is a simple, thank you.

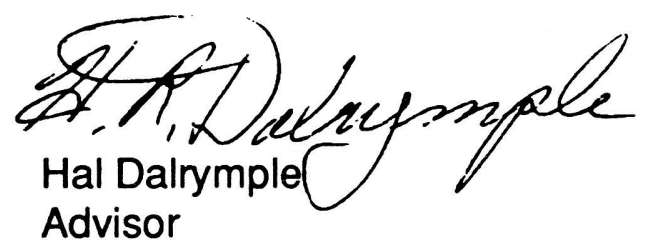




\section{Letter From the Editor}

I would like to welcome all of you to the Spring 1994 issue of Kaleidoscope. I am very excited with the quality of entries and thank each of you who took time to enter our Talent Track contest. The winners are to be congratulated but all of you who wrote, rewrote, then wrote once more before submitting publishable articles, are winners as well.

The number of entries decreased since our last issue, but I know you will be impressed with the literary genius displayed in what you are about to read. The selection process was not easy. It was difficult to refrain from publishing every contribution but you have our assurance that each entry was given our personal attention and discussion.

I would like to thank the Kaleidoscope staff for their support and dedication. To Vern Johnson, Editor Pro-tempe, thank you for your critical analysis when judging the entries. Matt Cutlip, Assistant Editor, displayed an enthusiasm concerning our fund-raisers and his contributions to these fund-raisers is deeply appreciated. Our Secretary-Treasurer, Marilyn Bryan always made available supplies we needed as well as keeping accurate financial records. Julie Warner, Eddie Phillips, Linda Phillips, Melody Colver, Mary Peck, Laura Callahan, and Kelly DiPolito helped make my role as editor not a job, but a pleasure. I must thank Professors Terry White, Roger Craik, and Harry Izenour together with student judges Tammy Wetherholt and Kelly Ingersoll. These friends of Kaleidoscope had the difficult task of determining which of the many excellent entries deserved to be winners. To our friend and advisor, Dr. Hal Dalrymple, thank you for giving us space to grow and learn on our own while reminding us you are always there if we need you. Lastly, a special thank you to Kerry Purkey and Lisa McConnell for their enthusiasm and dedication while assembling and printing the Kaleidoscope.

We will be accepting entries throughout the year for use in our monthly column, Kaleidoscope Korner which appears in The Rapier. We also look forward to the fall when we will once again begin the task of planning for Kaleidoscope, 1995.

Kaleidoscope, 1994 awaits you. Enjoy!

Gus Krage

Editor 


\section{KALEIDOSCOPE WINNER'S LIST}

\section{Spring 1994}

\section{Ant Winners}

1. Eve M. Birch--Cover Design

2. Tom Suhar--Untitled

3. Eve M. Birch--Untitled

4. Eve M. Birch--Untitled

\section{Honorable Mentions}

1. Tom Suhar--Untitled

2. Tom Suhar--Untitled

3. Eve M. Birch--Untitled

\section{Literary Winners}

1. Tammy Johnson, "It Once Was A Grand Olde House

2. Joyce Morse, "Spring Ahead"

3. Jennifer Roseberry, "Fortress

\section{Honorable Mentions}

1. Linda Chandler, "The Night the Tooth Fairy Fell Asleep on the Job"

2. Marilyn Bryan, "Before"

3. Theresa (Terri) Spicer, "Ode to the Great Hunter"

Other entries have also been selected for publication. 


\title{
It Once Was A Grand Old House
}

\author{
by Tammy Johnson
}

It once was a grand old house that sat upon a hill overlooking the grand countryside with its flowing rivers and giant shade trees. A stately mansion painted pearl white, surrounded by lilacs of lavender and pale pink. A house that was the home of the elite members of a society that has since diminished. A society that lived life to its fullest. But these elite members of society no longer exist, and their great great grandchildren don't intend to live in the past. This once exquisite home is now abandoned and left to the forces of nature to do with it what it may. Historical societies have sent out petitions. Local people with a thirst for nostalgia have been trying for years to save this marvelous home, but have not succeeded. The house has been destroyed. It no longer looks over the grand countryside, but we can recreate the life that went on there by using our imagination and our memories of what this grand home once meant to that elite society.

I believe that the most striking feature of this architectural masterpiece is the veranda. It wraps itself around the old place like a mother swaddling her newborn. I can envision the parties that went on here, with the festive lights blinking and champagne glasses clinking. Men dressed in white suits with arrow collars, carrying walking sticks. Ladies dressed in flowing gowns with their fingers mingling through their pearl chokers, as they talked with gentlemen. What a grand time. Glasses overflowing with bubbly and dancing to a lively beat until the sun came up. I would have liked to have been at one of these parties. To be a part of society that believed in living life instead of watching it pass by would be wonderful.

The parlor, as I envision it, is done in white wicker with large floral cushions. Youngsters find it amusing to jump up and down on the cushions until their mothers chase them outdoors. The walls are pale green and accented with family portraits. Aunt Georgiana's picture is the largest because she was the most beautiful woman in the family. She had auburn hair and the most striking blue eyes that could hypnotize even the most skeptical character. Alexandria's picture was the latest addition to the wall of portraits. She was born in May, when all the blooms had turned into floral works of art, and the smell of honeysuckle permeated the air. Every afternoon at 3 the ladies would meet for tea. They would laugh and giggle as they planned the social events of the season, which included strawberry socials and picnics prepared by the single young ladies as a way to meet suitors. The whole way of living was much more civilized then. Ladies were ladies and men were gentle. Social etiquette was demanded. This life can only be remembered as are the family portraits that occupy the walls.

The gazebo, which occupied a spot down by the lake, was an enchanting meeting place for aspiring romantics. Couples of every age enjoyed each other's company, while the moonlight danced over their shoulders, and the lake loon flew overhead calling its haunting call. Roses climbed the latticework that encompassed the structure, releasing the most wonderful scent that left ladies swooning and the gentlemen rushing to sweep them up. This was truly a glamorous life. A life that no longer exists, but can be revisited by walking the grounds of a once delightful home. Perhaps one day these magnificent homes will have life rushing past their wallpapered walls and brick terraces. Forgotten gardens will bloom, giving the appearance of a watercolor world, with pinks, yellows, lavenders, and reds, spilling off the palette. But for now, we only have a few spindles from the veranda that the workmen forgot to take. A smattering of pale green paint that floated through the air as the walls came crashing down. And a single red rose that continues to climb the remaining pattern of the latticework that once provided shelter for loving couples, giving life to a world that has died... 


\section{UNTITLED}

by Tom Suhar

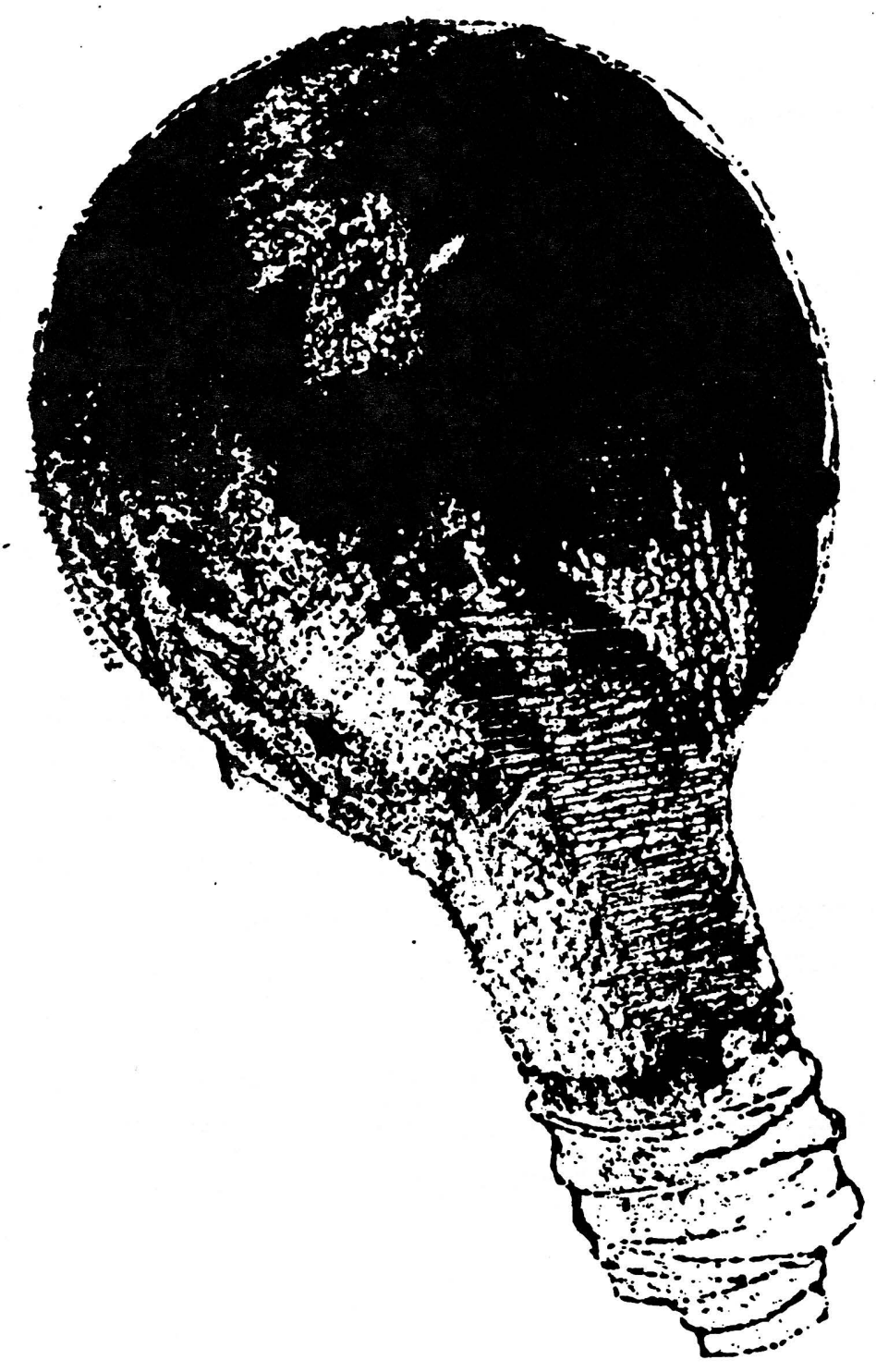




\title{
Spring Ahead
}

\author{
by Joyce Morse
}

The day was becoming beautiful. A week of rain had ended and a bright sun was drying the earth. School was good even for a Friday. Then, just before the dismissal bell, Mrs. Smythe asked us to please remind our parents to turn their clocks ahead on Saturday night. She explained that this is done every year, and that we would lose an hour of sleep that night. We had to memorize the saying "spring ahead, fall behind," which supposedly would always help each of us to remember about time and clocks.

How could I ever forget? Someone had decided to steal one hour from my life! Saturday night, while the whole world slept, there would never be a two o'clock because the hour hand on the all the clocks would bypass the two and pass on to the three. No one seemed to be concerned. One hour is a very long time; it's sixty minutes, which is the same as 3,600 seconds. I'm good at arithmetic so I know these numbers are correct. I can do a lot of very important things during a period this long.

I rushed home to my mother thinking that maybe things weren't so doomed. She's always saying "Time is precious, Don't waste it." She would never let anyone steal a whole hour from her family. She agreed with Mrs. Smythe, as did my father. The clocks would be pushed ahead.

The sun is rising and the roosters are crowing so I really don't have to" look at the clock. I glance at it anyway. It's a little after six. Tonight, time springs ahead. I wonder if the roosters will crow at six tomorrow morning, which will be the real five. Maybe they will crow at seven because seven will be the real six. I cannot ask my parents. They think all my concerns are silly and have forbidden any more discussion about time or clocks. I feel good right now, probably because I've had eight hours of sleep and I know that by seven I will be seated at the table eating my usual breakfast.

After having lost an hour, l'll be tired tomorrow morning; and since seven will really be six, I won't have much appetite. I will get sick. Dad said that the hour I lose will be given back in October, but if I get sicker and sicker and then die I will never get the time back. How will I ever know my true age if hours are stolen and then returned! These hours have to be accounted for.

I wonder if God knows about this tampering with His universe. He might be very upset when He checks up on the churches at eleven tomorrow morning and finds them all empty. All of us might find out what His wrath consists of. It's probably a lot worse than anything Mrs. Smythe could imagine.

Oh, no! Roger is screeching; it must be six-thirty. He's three years old but still thinks that lying in bed and yelling as loudly as he can is the only way to wake up. He always howls at six-thirty. Tomorrow that time slot will be called seven-thirty. I may not be completely doomed. 


\section{UNTITLED}

by Eve M. Birch

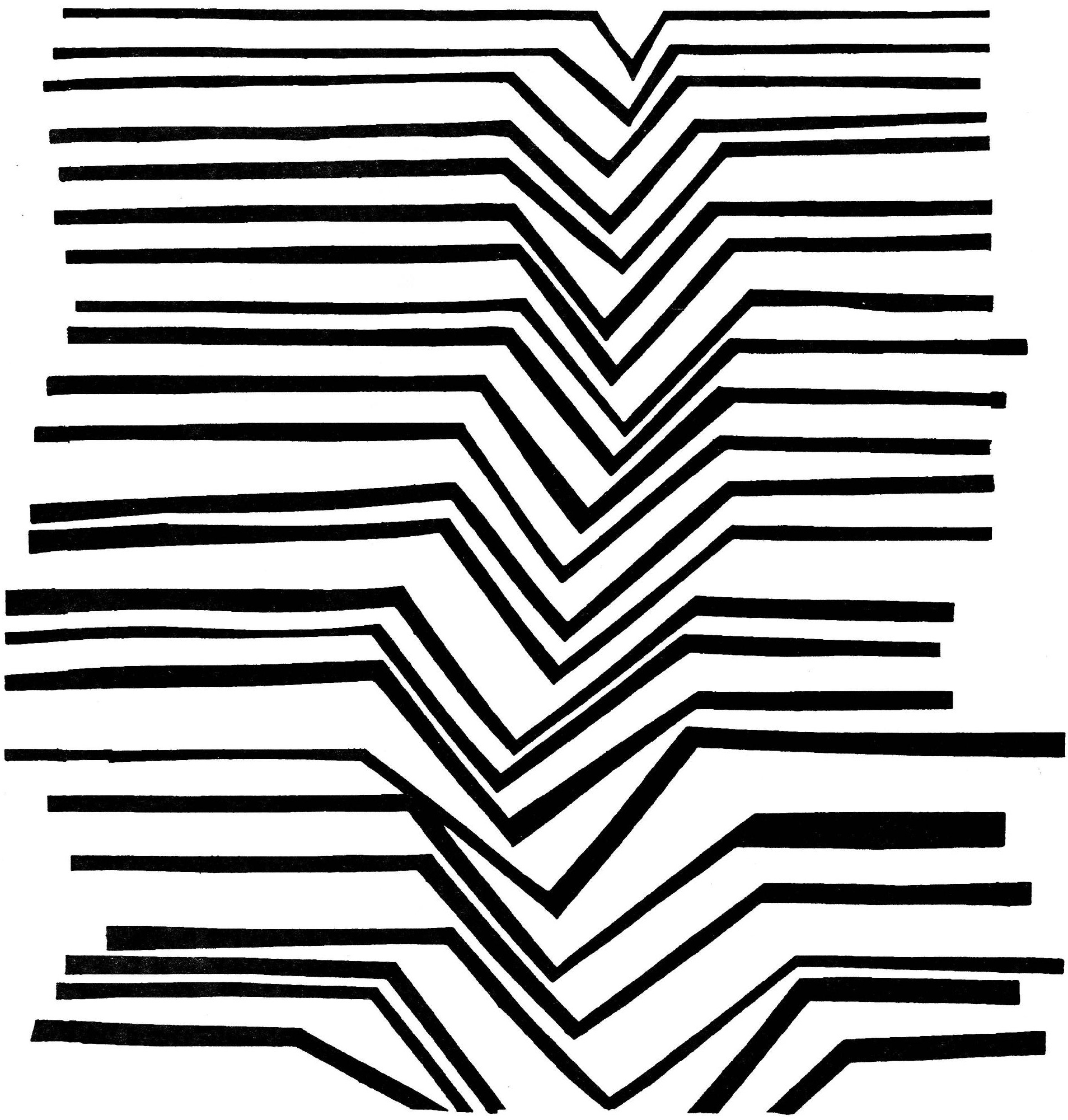




\section{FORTRESS}

\section{by Jennifer Roseberry}

There is strength in the number

of your secrets, reinforced with

Self-control, an impenetrable

fortress.

Whereas I,

Enamored lie,

\section{Elation}

Beneath

Your

Firm

Gaze. 


\section{UNTITLED}

\section{by Eve M. Birch}
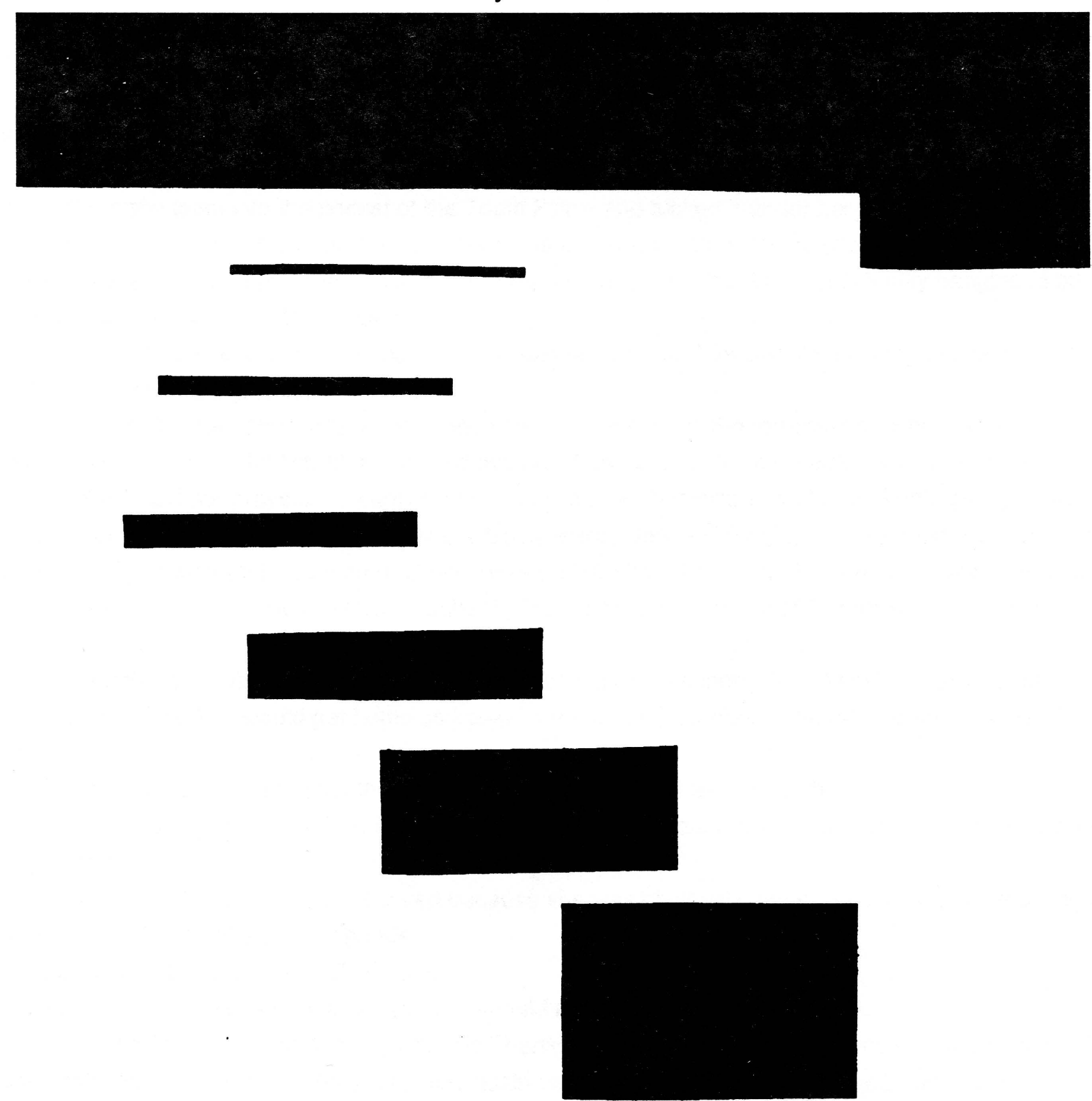


\title{
The Night the Tooth Fairy \\ Fell Asleep on the Job
}

\author{
by Linda Chandler
}

My six-year-old daughter, Kelly, was ecstatic as we climbed upstairs to tuck her into bed. Before jumping under the covers, she disappeared into her closet and triumphantly reappeared with the Tooth Pillow.

I had almost forgotten that earlier that day, Grandma had pulled out Kelly's loose front tooth. Kelly deposited the tiny baby tooth into the pocket of the Tooth Pillow and tucked it under her own large bed pillow.

"The Tooth Fairy is coming tonight," she lisped as air escaped through the gap in her grin.

Kelly was a comical sight with one front tooth missing and the other front tooth jautily hanging at an odd angle because it was ready to fall out, too.

I told her, "By the time Santa comes, you'll be singing 'All I want for Christmas is my two front teeth..."'

"No way," she said giggling.

The first draft of her Christmas list included almost everything in the toy catalog. She had spent the last two weeks paring down the list, and I realized two new front teeth definitely would be a low priority.

After Kelly said her prayers, I wearily trudged downstairs. Tomorrow would be Thanksgiving. I was exhausted, but I still had to bake five pies for our family feast. Before mixing up the pie crust, I checked my purse for Tooth Fairy money and discovered all I had was a $\$ 5.00$ bill. The Tooth Fairy traditionally leaves $\$ 2$ at our house. I made a mental note to ask my husband, Rick, if he had a couple of $\$ 1$ bills when he got home from work at midnight.

I finished the pies late that night and left them to cool on the kitchen shelf. I set the alarm to get up about the same time that Rick would get home so I could put the pumpkin pies in the refrigerator and play Tooth Fairy.

I foggily recall getting up to put the pies away, but that's about all I remember.

The next morning, Kelly was the first one up. She came into our bedroom with a sad face. Tears were ready to spill out of her eyes.

"What's the matter?" I gasped, startled because she was obviously upset. As I jerked into a sitting position, I saw the Tooth Pillow in her hands.

"The Tooth Fairy didn't come," she sobbed.

Guilt swept over me like a tidal wave. How could I have forgotten?

"Maybe the Tooth Fairy took a day off. It is Thanksgiving, you know," I said lamely, trying to comfort her. "Why don't you try putting it under your pillow again tonight. I bet the Tooth Fairy will come tonight."

"OK," she said, with a glimmer of hope in her eyes.

She bounced out of the room, once again a carefree six-year-old.

As I collapsed back onto my pillow, Rick gave me a quizzical look. "What was that all about?" he asked.

"The Tooth Fairy fell asleep on the job last night," I confessed. 
First Honorable Mention

\title{
UNTITLED
}

\author{
by Tom Suhar
}

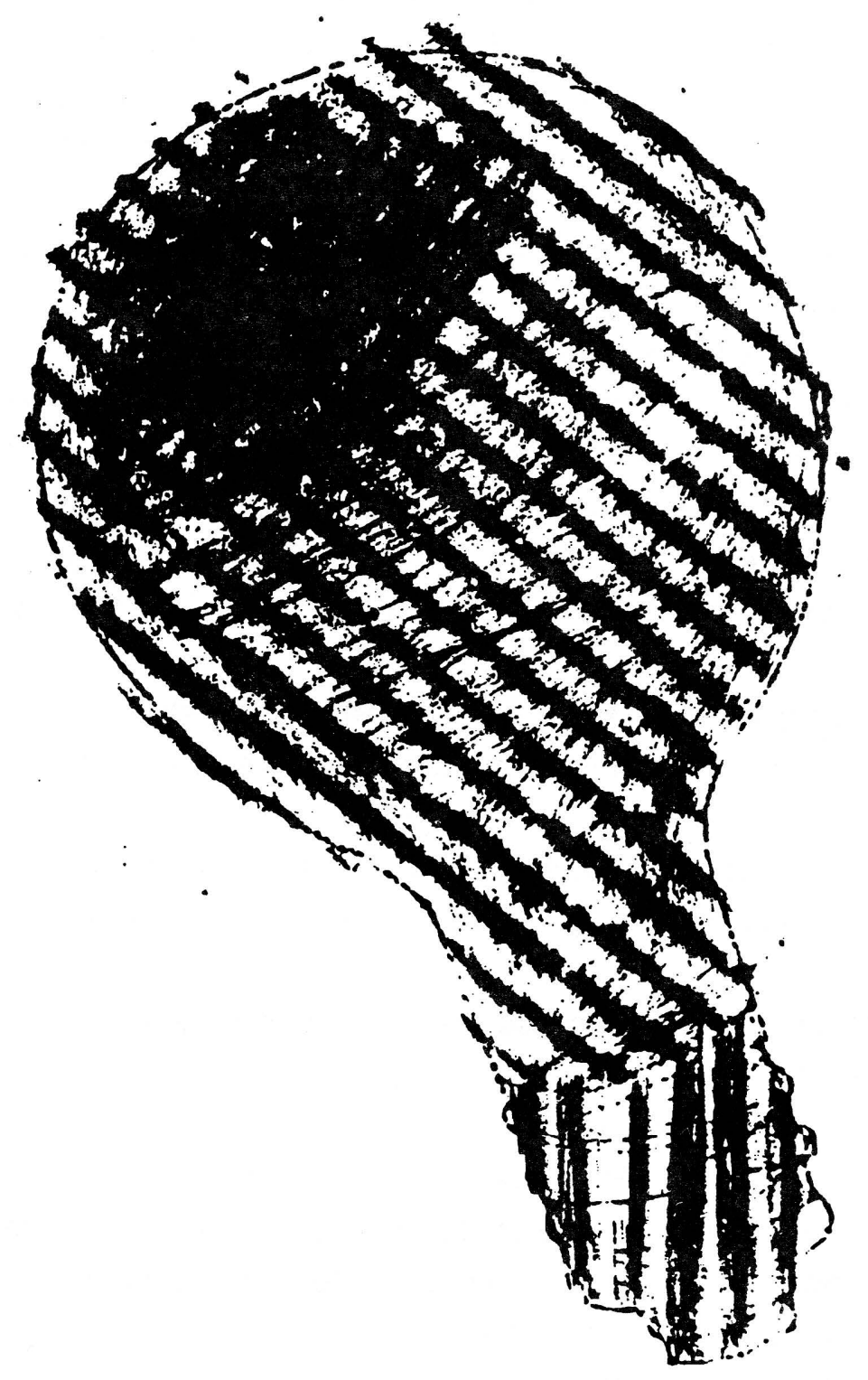




\title{
BEFORE
}

\author{
by Marilyn Bryan
}

Before I met you,

I never knew the meaning of true love.

All I knew was pain.

All I knew was emptiness and loneliness.

Now that l've met you,

You have shown me just how wonderful

Real love can be by your touch, your smile, your every action. 


\section{UNTITLED}

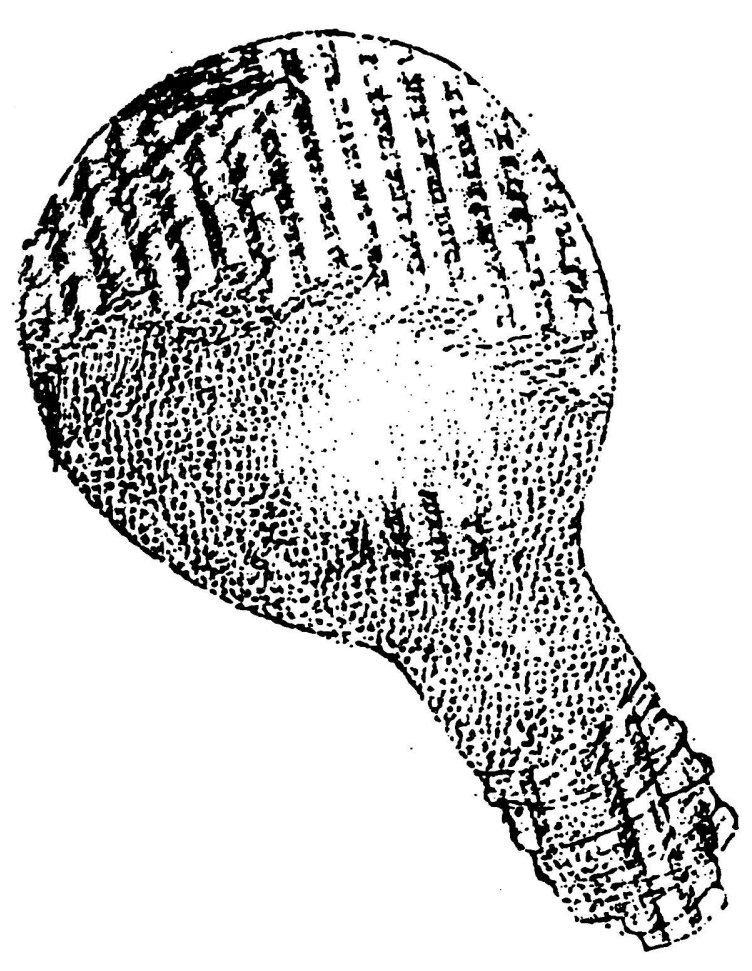

by Tom Suhar
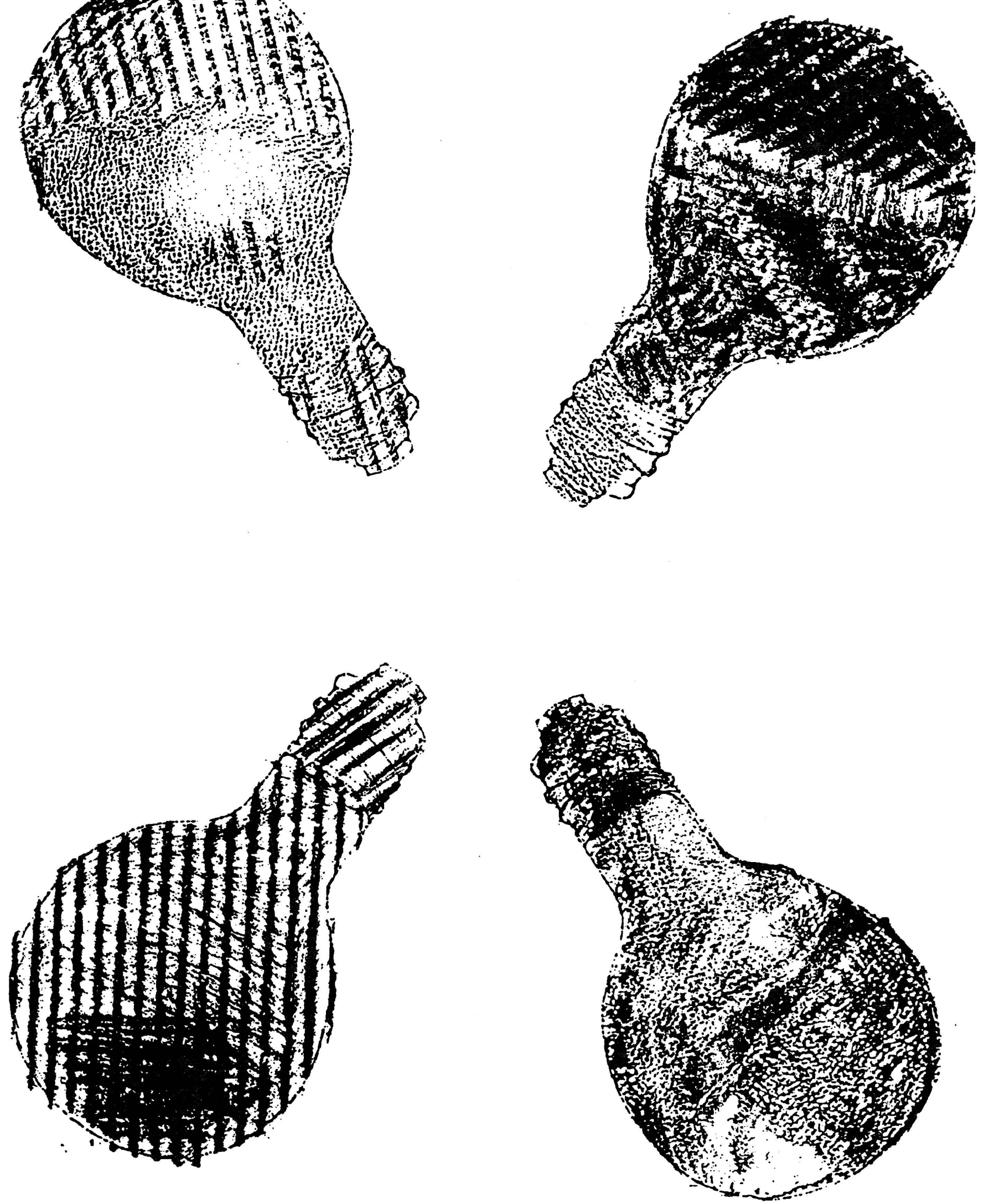


\title{
Third Honorable Mention
}

\section{Ode to the Great Hunter}

\author{
by Theresa (Terri) Spicer
}

Hunting season...yes, it's that time of year again. It's time to be enthusiastic about stories of the Great Hunter's adventures.... if you can understand them.

The Great Hunter is an unique species of human. If the Great Hunter ever gets you in his sights, look out! I was almost a victim, and let me tell you I saw my life pass before my eyes. It all started simply enough, by asking the question, "What have you been doing?" That's when it became evident to the Great Hunter that I was an easy target. He started the story of his latest adventurous trek through the woods, on a quest for the Ultimate Kill. It took only a few sentences before I realized that I was in grave danger. Let me highlight the story to you from my point of view:

The Great Hunter opened his story with the line, "I bagged a deer." The term, "Bagged a deer"...or animal for that matter...was completely foreign to me. Does that mean you put a bag over its head before you shoot it? Does it mean you placed it in a plastic bag before freezing? I pondered these questions for a moment. Then in a confused tone, I did the unthinkable. I asked the Great Hunter the question "What are you talking about?" The look I received gave me a clue that it may get rough, as the Great Hunter's story continued to unfold. The Great Hunter explained--with a frustrated tone--that "Bag a deer" simply means, killed it. I continued to wonder where the "Bag" fit into the picture as he proceeded on with the story.

Then it happened again...another term hit me between the eyes, and again I was bewildered. "I got a button," he said with a sense of pride. I thought, "Well, I have many of them and I feel sorry for anyone who has only one." Since I was on a roll of ignorance, I again enquired as to the meaning of "Button." The reply, "A Button is a young buck," was supplied.

Then came the chapter in the Great Hunter's story that put me over the edge of stupidity. When the details of the type of weapon and ammunition used were conveyed-of course this was told using the Great Hunter's jargon--I knew my end was near. At this point, I stopped asking questions, I smiled, nodded my head, and tuned out the rest of the story.

After the Great Hunter's story had come to an end, he turned to me and said with all seriousness, "You should come hunting with me. I have a ....[some type of gun or another]..that would be perfect for you to shoot." Has this entire world gone nuts or just this Great Hunter? I haven't even a remote understanding of the details of the story he just told and he is going to put a firearm--a deadly weapon--into my hands?... Loaded?

By now, I had realized the insanity that had gripped the Great Hunter. My reply to him, given in a matter-offact way, "I have to use the bathroom." It was then that I made my escape from the Great Hunter.

I guess I'm what the Great Hunter calls, "The one that got away." 
Third Honorable Mention

\section{UNTITLED}

by Eve M. Birch

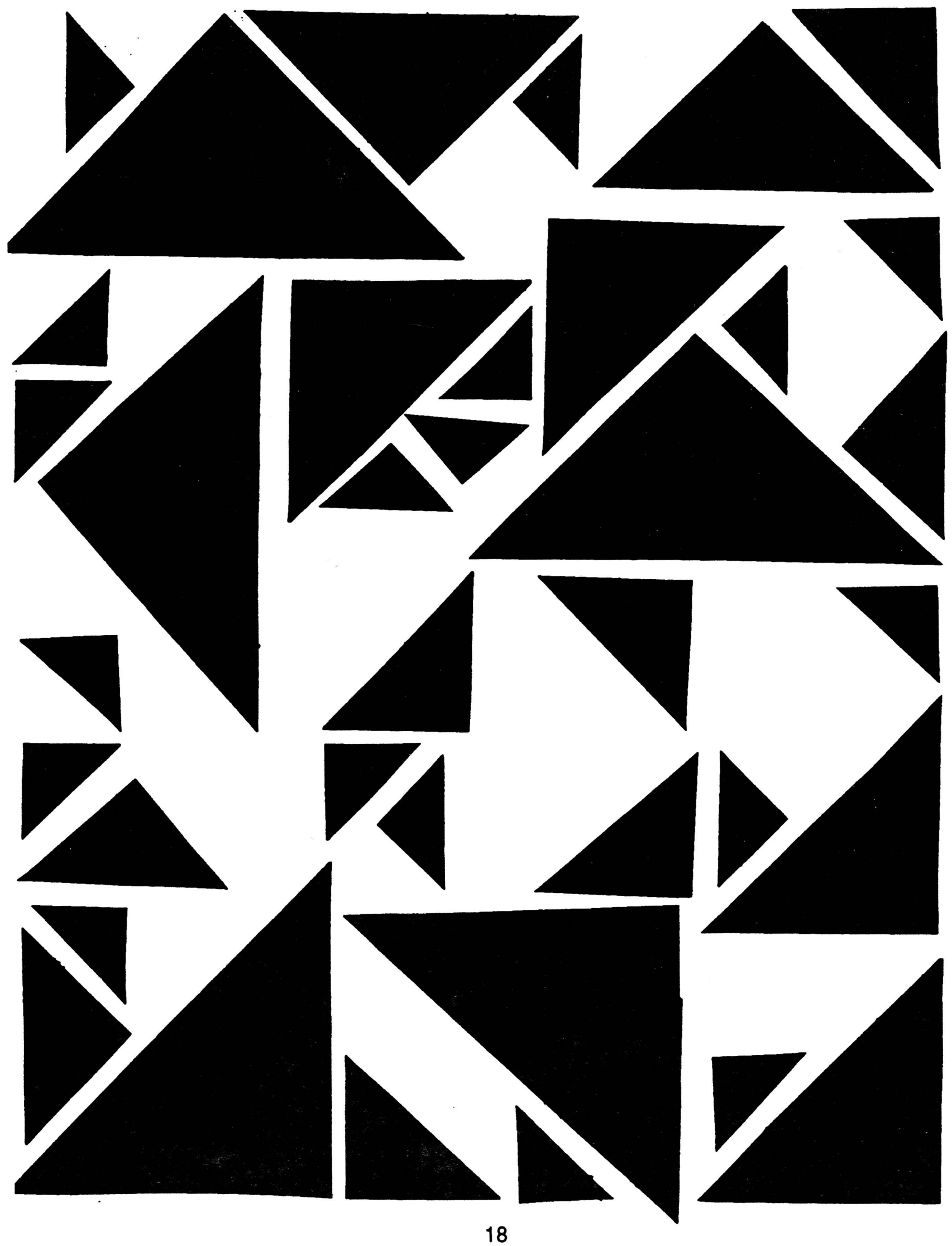




\title{
Jenny
}

\author{
by Gus Krage
}

Dogs have long been thought of as "man's best friend." I recently discovered they can also be excellent teachers. This insight came to me during what I thought would be the rather mundane task of walking my neighbor's dog.

Jenny, a frisky, black, overweight miniature terrier, had the speed and grace of a greyhound even though she was approaching her sixteenth birthday. She bolted ahead of me in an attempt to run but then fell back trying in her own way to please me. I struggled to keep control of the dog and the leash. I reminded myself that Jenny was an obedience school dropout, so when she looked at me with her pleading, piercing, black eyes, I had no choice but to pat her graying head instead of disciplining her for not listening to me.

When I saw that we were alone in the darkening park I let Jenny off her leash. This was a rare treat for this couch potato dog to do what she did best; to run fast and free, to sniff and explore the trees and bushes at will. On these special occasions when Jenny was given this freedom, she usually stayed nearby and obeyed me with a respect and devotion I had not found in anyone.

Soon, a large grey squirrel ambled into our line of sight. This was no ordinary squirrel! It boldly approached Jenny as if to say "Catch me if you can." Showing no fear the tiny intruder refused to scamper up a tree for protection. When the squirrel decided to play a bit Jenny began her pursuit. Ignoring my command to stop she dashed here and there having as grand a time as the squirrel. The chase ended abruptly when Jenny increased her speed to her personal best, overshot the squirrel and did a back flip trying to get back on course. By this time the victorious squirrel was safely up an oak tree smugly leering down at the two of us. Showing no signs of frustration or concern about her unplanned gymnastics, Jenny calmly continued her tour of the bushes and trees.

I laughed in relief and amazement! It occurred to me to wonder how I would have felt if it had been me doing the back flip instead of Jenny. Gingerly picking myself up (assuming that I could get up at all) I would have nervously scanned the area to see if anyone had seen me fall. This ego has kept me from allowing spontaneity to be part of my life. I have truly sacrificed for matters that are not that important.

I realized that dogs operate on the premise that life is too short to let an embarrassing situation spoil a good time; they just do the best they can, have fun and live for the moment.

The sound of a honking goose brought me back to reality. I took Jenny's leash from the bench and called her. There was no response. I called her once again "Here, Jenny. Time to go, girl." Still no response. I decided to walk down the path in search of her. As I made my way through dense thicket I saw a tiny bundle nestled in a pile of dry leaves. It was Jenny. Her body was still warm. I carried her in my arms to the car. I hoped that when it was my time to die I would be as fortunate as Jenny, to have spent my final moments like Jenny, doing what I most enjoyed! 


\title{
The Hunt
}

\author{
by Matthew D. Cutlip
}

It was a clear spring morning when the whole affair began. I was walking through the halls of Kent State, Ashtabula Campus. Suddenly I realized that it was Fox season. I am not talking about the big ones mind you. I am talking about miniature foxes. If you do not believe they exist, why are there miniature horses, elephants, and rhinos?

I went home to gather the necessary equipment; mainly some money for telephone calls to various agencies. I went down the driveway as usual. This time, there was a feeling of anticipation in the air. Gus picked me up. He, too, could feel the slight tingling in the air. The hunt was on!

We went into the modern jungle, feeling that this was going to be easy. It was not of course, but we did not know it at the time. Many people had the idea to hunt something that day. We saw a great many wild boars with their humongous guts hanging out in front of them, pushing everyone out of their way. There was also a large number of deer with their soft eyes twinkling merrily and shyly at every human they passed. A good number of attractive members of the human race were also hunting. My goodness, we had a hard time getting around!

We went from place to place seeking knowledge on the whereabouts of the mysterious and illustrious miniature foxes; anyplace we could think of that might know the area where the things "lived" we checked out. Of course, we found a few things along the way that we decided to keep. We gave up on the one area and decided to check another out the following week.

There seemed to be more people in this jungle than in the last. We came up with the same "successes" as our last adventure. We could find no information about these magnificent creatures. Indeed, the people we talked with hunted them anyway. This is not to say, however, they are endangered or that it is illegal to hunt them. This is merely to say they are rarely seen and that not many people want to take the trouble of hunting them.

We fell into a routine. Every week for several weeks in a row, we checked out another jungle. The people always said the same thing, "We can't find them anywhere." We saw miniature clams and caterpillars and other miniatures one could imagine, but no foxes!

We started to get desperate. All of our many searches had turned up nothing. We began to wonder, ourselves, how anyone had managed to capture these elusive critters.

Gus and I came to a dismal conclusion. We did not want to even consider the idea but we had no choice whatsoever. There are no crystal foxes in any of the malls in Northeast Ohio or Northwest Pennsylvania. The hunt is over for the present but we will never stop wondering how it would feel to hold a miniature crystal fox in our hands! 


\section{MARSHFOLK}

\section{by Jennifer Roseberry}

The darter takes flight

Falters momentarily--

then resumes

Spiriting over glass surfaced marshes

Cracked silence

By the loon. 


\title{
The Christmas Gift
}

\author{
by Gus Krage
}

Christmas, 1979...it was anything but merry with no resemblance to a time of holiday joy. I had been confined in a rehabilitation center for over three months, five hundred miles from my family. I was totally alone. Those patients who lived nearby or were physically able were allowed to go home for the day while those of us who remained had nothing to do but try to remember what a family Christmas was really like. Christmas? It was more like Christmess!

When the so-called "merry" day finally arrived, in order to relieve our blues, boredom and bitterness, we decided to visit those patients who were unable to leave their beds. We proceeded from floor to floor until we arrived at Mary's room. Mary! You loved her or despised her, prayed for her or scorned her. She had been placed in our rehabilitation center until a room was available in the local nursing facility. Her family no longer wanted the responsibility of taking care of her. Mary was very bitter, deeply depressed and extremely angry at herself for being such a burden. She resented those who treated her as if she had a contagious disease. Mary would sit in her steel grey wheelchair for hours, watching everyone pass by.

Mary had not talked for over thirty years. Her family had been enjoying a day at the beach. When lunch was over her husband decided to take the children fishing. They chartered a boat for an afternoon of fun. Within minutes an unexpected summer storm converged on the area. Mary looked on in horror as the small boat capsized. Her loving family perished. She never spoke a word since that tragic day.

Our group voted unanimously to boycott Mary's room. Any gesture she received was always returned with a slapping of her mahogany cane on whichever part of your anatomy she could reach. Mary preferred to be alone. She ignored anyone who attempted to converse with her. We felt very uncomfortable with her since our conversations were always one-sided. Our "sick clique" had nothing in common with this old, angry lady. We also felt guilty for not making the effort to be friendlier.

For some unknown reason I motioned for the group to go ahead. I timidly entered her room. As usual I was greeted with a look of caution coupled with sad, angry eyes. But I felt Mary deserved a Christmas like everyone else. I began singing Silent Night, tears streaming down my haggard face. Mary looked at me as tiny teardrops brushed her wrinkled skin. I approached her with much apprehension and without realizing it, I bent down placing a kiss on her sandpapered cheeks. I expected to be physically reprimanded for violating her privacy. I was not, however, prepared for an experience I will never forget. Mary held my hand tightly. Her parched lips slowly formed the words Silent Night, first very quietly then with the enthusiasm of a young child. An unhampered joy filled the halls.

Nurses and doctors hurried to Mary's room; she had uttered her first words in over thirty years! Silent Night turned into Deck the Halls. For more than one hour, Mary joined me as we sang all of our Christmas favorites. We cried as we held each other. The love of the New Born Saviour embraced us. A Christmas miracle had taken place. Two people from different backgrounds but with the same feelings of depression, anger and loneliness had discovered the true meaning of Christmas in a most unusual place.

Throughout the years I have spent many Christmasses with my family. The gifts have been abundant, the love overwhelming. I will, however, never forget that special Christmas when I had been stripped of family, friends, dignity as well as material possessions. But I was blessed instead with the gifts of true love and inner peace. 
If I could give to all of you a Christmas gift that would remain with you long after the holiday season has passed it would be that you develop the desire to take that extra step, to reach out as I did to that one person who is alone and rejected, for in the loneliest person you may discover the strongest blessing!

by Gus Krage

I awaken in sadness,

I CRY.

I curse another dawn,

I CRY.

I look into myself,

I CRY.

I see no reflection

I CRY.

I leave my sanctuary,

I CRY.

I am devoured by beasts,

I CRY.

I pain from their bruises,

I CRY.

I enter my soul,

I CRY.

I turn off the light,

I CRY.

I fear another darkness,

I CRY.

I cry because I cry,

I CRY, I CR, IY, I. . . 


\section{Mystery}

by Matthew D. Cutlip

The world has a long time

to live,

Yet we, as humans, do not,

The wonders of the nature

are waiting.

We must grasp them while we still may draw breath. 


\section{UNTITLED}

by Eve M. Birch

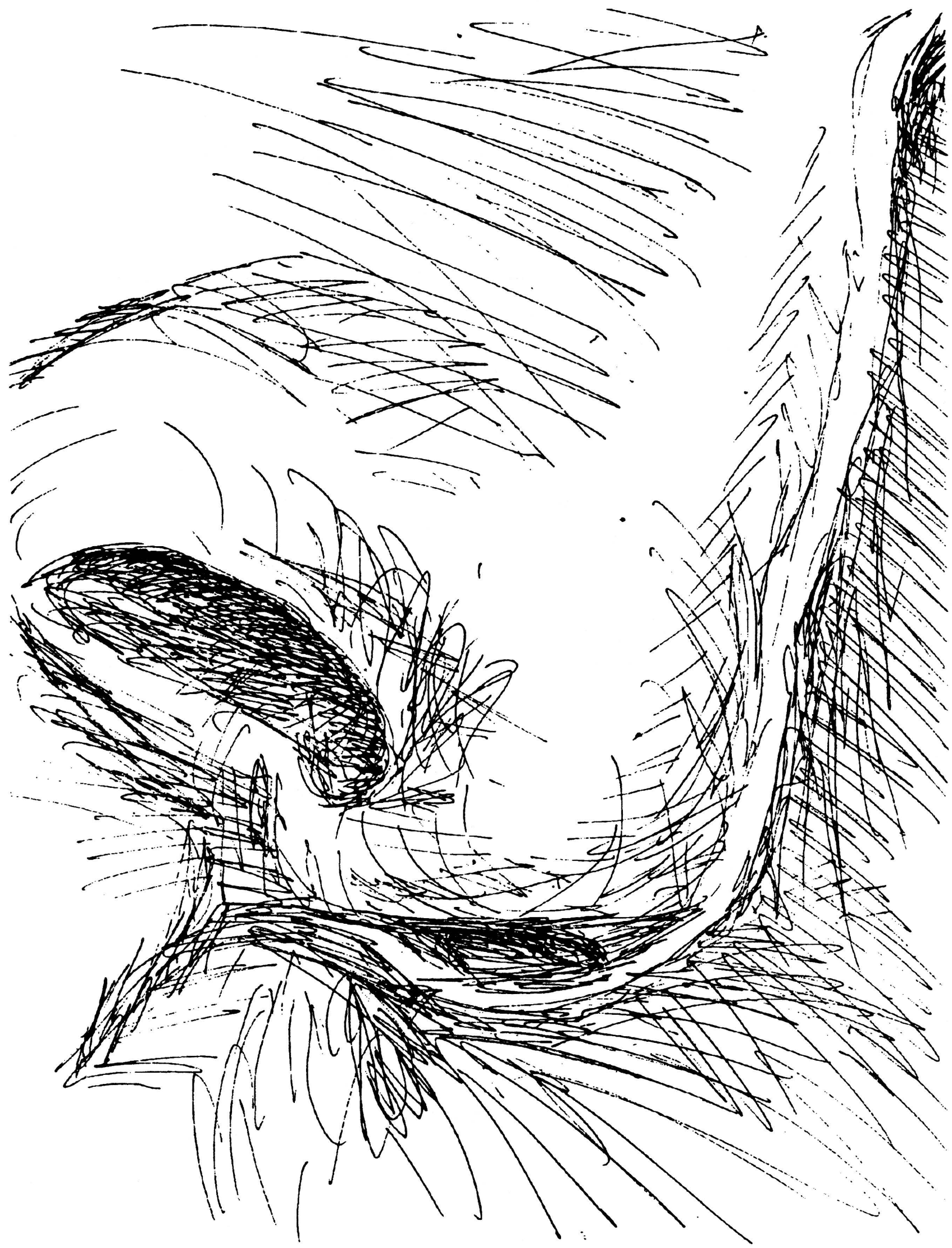




\section{Harm's Way}

\section{by Susan Powers}

I have six brothers and a sister. I've had some experiences and problems l've overcome in my life by being in a large family that l'd like to share with you. It was hard being in a large family. Here are just a few examples of how it was.

We moved to Ohio when Keiren, the youngest, was born. My dad worked for Lubrizol and my mom would soon become a teacher at Assumption School where we all went to school. Our house wasn't huge, but it fit us all. I shared a room with my sister and my brothers split three bedrooms, two boys in each room. People made fun of us. Stupid jokes like, "You guys should start your own baseball team," and "Didn't your parents know when to quit?", were often heard in our neighborhood. They liked to make fun of our parents a lot, calling them drunks and other names. We had to stick together to survive.

As we grew older, life got harder. We handed down clothee another, shared shoes and boots, and fought with each other. I could never understand why two of my brothers fought with each other most of the time. We had enough to worry about trying to stay out of harm's way, harm being our father. My father was an alcoholic. My mother drank too, more so after my father died in 1981. The difference was that my father got violent, my mother, on the other hand, got depressed. We tried our best to protect each other. Some nights we'd all sleep in the same room, hoping our father would leave us alone and go to bed.

My memories are pretty vague of when our dad got sick. When I was 12 , I remember going to see him in two different hospitals. My Aunt Anita came to help our mom out around the house. Then I remember the night he died. We were all watching TV's, "Benny Hill," and our mom came and said it was time to say goodbye to our father. We all went and said our good-byes, one-by-one. Then we were sent to the neighbor's house so the priest and doctor could do what they had to do. We all sat on the floor, as a family, and prayed. I recall kissing my dad on his cold forehead at the funeral home. Then there was a get-together at our house. My brothers and sister have their own memories of that time and each of ours is different. I'll never forget how cold his forehead was.

I used to always say, "If anything ever happened to my mother, l'd fall apart." Well, my mother got sick in the Spring of 1988. As it turns out, I didn't fall apart. I took on much responsibility. It was all very sudden and very life-threatening for my mother. Since I was the oldest at home, I had to make some crucial decisions, ones I wish I wouldn't have had to make. My brothers and sister said they supported me no matter what. The decision was to go for it and try to pull her out of this. She came out of Cleveland University Hospital and came home in the Spring of 1989, a long year after she became ill.

We tried to take care of her at home, but there was just too much we couldn't do. She was paralyzed on the right side, on dialysis, a diabetic, and wouldn't cooperate with taking her pills or doing her exercises. Everyone had to go back tojis or her life and that left me and Keiren at home. I had to work and Keiren was still in high school. In the Fall of 1989, I had to put my mother in a nursing home. I say, "I" because I looked for the right one, I signed the paper work, and I took her there. My family supported me, but I felt like I had done the worst thing possible you could do to your mother.

I visited my mother as often as I could and my brothers and sister did the same. She did pretty well at the nursing home. Learning to walk with a cane was her biggest accomplishment. She got to see three of her children marry and see her first two grandchildren. My daughter, Brittany, was the first. I guess she thought 
she'd seen enough, and in August of 1992, she got sick again. I was the contact for the nursing home, so they called me. I went there knowing my mom wouldn't want to go the emergency room, but I made them take her. By the time I met the ambulance there, she was worse. The doctors told me that if they didn't stick a tube down her throat to open her airway she was going to die. I told them to do it and I went and called my family. I had a feeling she wasn't going to make it so I asked everyone to come home as soon as they could. We spent many hours in the waiting room deciding our mother's fate. After ten long days we let her go. She had done her job on earth and suffered enough. She wasn't the person she was before, and we all knew it. On August 20, 1992, soon after we had her machines turned off, our mother died. She was only 51 years old. We buried her four days later. Before we all left the cemetery, my brother placed a picture on the top of her casket. It was a picture of my mother and her eight children.

There are feelings that all of us will feel for the rest of our lives. More situations and problems will arise as time goes by, but we've got each other. Together, we'll survive. 


\title{
I WANT......
}

\section{by Russell (Rusty) Wagoner}

\author{
I hear her but my ears don't listen \\ I yearn for her but she does not recept \\ I need her for nothing is complete \\ I imagine her but it is not real \\ I smell her but nothing makes sense \\ I think of her and infinity is a factor \\ I notice her but nothing takes action \\ I take her but wishing won't prevail \\ I love her and yet she does not know \\ I feel her but the numbness sets in \\ I had her but now my life is over \\ I want her........
}




\section{TIME}

by Kim Slapak

The smell of hot wax brings me warmth

As I stare at winter through the window.

My thoughts are neither here nor there

Time passing, to my heart, seems too slow.

A certain dread consumes my being

When I remember the life of my past.

That cold grip of fear that controlled

my breathing

Was drowning me until at last--

With a fierce need to survive

And rediscover who I was before;

The search through the past yet for a

future collide,

And together were the keys to the door...

Now the waves are gone and the breeze

is light,

And the sun warms my skin through the pane.

The tears are dry and the fear behind,

And now time and hope remain. 


\section{UNTITLED}

by Paul Kucharski, Jr.

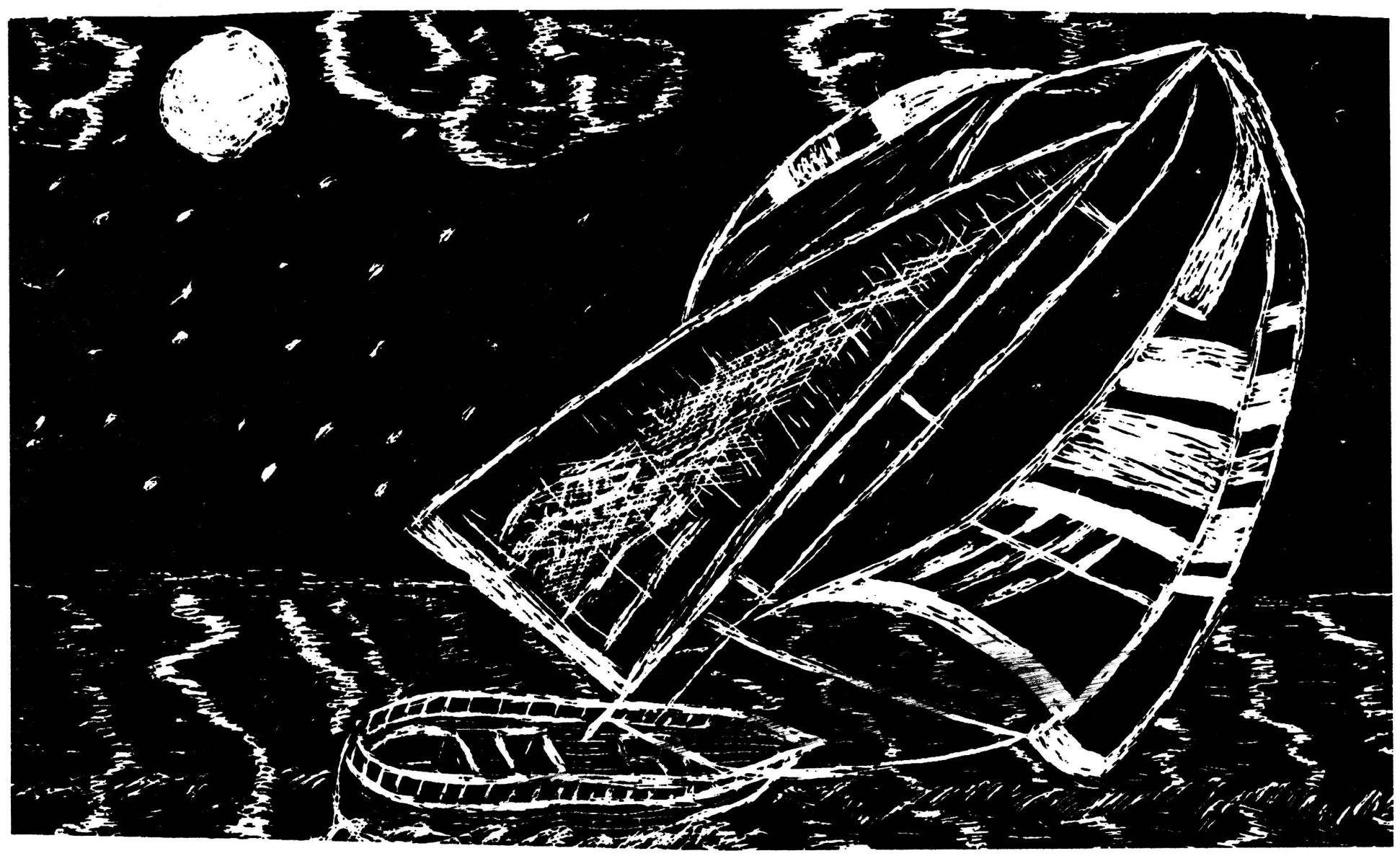




\section{WONDER}

by Marilyn Bryan

As I sift through the rubble of my broken dreams,

I wonder how to pick up the pieces of my past.

Just what do I keep?

What do I discard?

What went wrong?

I know not.

Could I have tried a little harder?

I think not.

Always hoping for a love that lasts.

I know not what my future brings.

But there is one thing of which I'm sure.

I'll get by, no matter what. 


\section{MARCH 13, 1993}

by Charlotte Hutson (Fitzgerald)

\section{Morning}

The clouds fill the sky.

Love fills the air.

Mid-Morning

The white flakes fall from the sky, crashing on the ground as if to smash the dream.

\section{Early Afternoon}

The flakes now knee-high, visibility zero.

The hall half-filled, the love never-ending.

\section{Late Afternoon}

Wind now blowing, flakes still crashing, I do's are done, people are gone.

\section{Early Evening}

Visibility zero, white sand is waist-high, united as one, our never-ending love won't be halted, by the storm of the century. 


\title{
UNiDenTIfiEd \\ bY: A SChizOpHrenIC NEurOLogiSt Mime
}

\author{
by Russell (Rusty) Wagoner
}

Help for I have fallen and myself won't help me up......

I don't think he thinks he likes us.....

But most of all he pays no attention to me.....

He dreams of us walking through a meadow.....

But I don't care for the smell of our aftershave....

Why won't I leave us alone......

I'm scared to run for he knows where we go....

I can't seem to lose him for he keeps winning...

He has no money...I have all the time......

I hate meat...He loathes asparagus...

We might agree on pizza....

But who's counting anyway...

I hate bright light......

He's afraid of the dark...

Why can't we be a team and kill each other...

His brain is smaller than mine.....

But he's not actually seen ours...

We have a notion to punch myself.....

Where did he put the band-aids.

I like Nickelodeon....

He loves documentraries

I slap myself for what we've done....

And still the picture's hazy...

He controls the vertical hold.....

And I control the horizontal.

Hypodermic needles injected in our skull...

Queezy little dwarfs hanging from my towel rack...

What have we done with his golf balls...

It's in the sink Derf, it's in the sink....

Be happy with what I think...

And ask no more questions for we already know the answers....

Pick us up..release me from my floor...

What are you doing with that plunger.....

Numbness sets into our left arm.....

No control left...take it off our head....

Help me up...our butt is stuck to his bathroom floor...

We don't think it's funny anymore Derf....... 


\title{
FIRE IN THE SEA \\ Journal Entries of Christian Cooke, Cabin Boy
}

\author{
by Mark G. Reffner
}

\section{Chapter 3: The Rest of the Traveler}

A red pagan mist clouds the remembrance of my first week on the boatless Blue Island. This was the place of shimmering water and sumptuous forests. A lush, cool sister among a coven of molten rocks, lost in the Atlantic somewhere east of North Africa.

At age 17, I was surely lost to my world of 1915 Pennsylvania, USA. And my world was lost to me. I was as if dead.

But Uhuru-Mali saved me. A tall fearless native woman, she leapt from a fearsome cliff and plunged into the deep sea like a black dolphin, to drag me from a drowner's death in her vast lagoon, giving me new life. Her potent medicines and soothing voice made my oceanic terrors fade, and on my second (or third?) morning ashore, I felt well enough to coax my beautiful nurse into letting me stroll on her white beach. Scanning the island recesses above me. Breathing the cool morning sweetness of a fruitful land beyond the high cliffs.

Beautiful. I had never really noticed black women back in my American home. Or even in the African ports. But Mali--tall, glossy-haired, of Olympian strength--this woman was undeniably handsome, and studying her plum cheeks and exquisite eyes, I decided that yes, she is beautiful.

For a savage, she was remarkably fragrant, clean, and reasonably modest. She liked to pretty herself. And she was wonderfully tender. I realized this when I found myself face-down in the warm sand, and ever so caringly, without a breath of reproach, the woman lifted me from where I had dropped and brushed the sand from my face and straw-gold hair. And from my belted linen robe. "Poor Christian," she smiled gently. She knew I felt humiliated. "Not to worry now, o-kay? You get bettah soon. O-kay? Not to worry." How she had learned her mariners' English, I did not yet know.

Shakily I mumbled, "I guess I fainted. I, I didn't think that would happen," lamely. Suddenly my light new strength was flown, and a cold aching vacuum pierced me in its place. "Just," I blinked, "just help me stand up."

"May swit buoy," she murmured as I walked unsteadily with her strong satin arm around me. "Mali carry you, yes? You be very light. O-kay?"

"Thanks, but l'd rather, rather walk," as I faltered again. Flames of heat seemed to build up over my skin, and I toppled into a smoldering red netherland, like a helpless idiot.

Vaguely aware that my friend had carried me back to her woven hut, I cracked open my eyes, and my own heat seemed to shimmer up across her somber face. A fresh blanket covered me from the waist down. "I'm sorry, Mali," I croaked, crestfallen. A day and two nights in the Atlantic had whipped me worse than I realized. "I guess I'm pretty useless."

"No-no, may swit buoy," she cooed, and I heard the spangle of dripping water beside her smooth knees. Lifting a flooded cloth, she let the cool water run onto my tormented arms and face. Careful not to rub my screaming skin. "Poor Christian. The great ocean hava swallow you, and fill you, and fire of sun et your skin. 
Looking at my scarlet arms and torso, quivering on the fragrant grass mat, I knew she was right. The sunlight of a long balmy day had shone right through the seawater and burnt my white cabinboy's skin lobsterbright. "O Christ," I choked. "I'm cooked. I'm burnt to death."

"No, lil' brother," she promised, sending eels of mentholated water across my chest. "Your poor skin, it peel off two, maybe three time o-kay. Not bad. But sea and sun maybe hava pour down inside you? Inside ribs. And steal breath." Maybe she had previously seen fishermen, or fisherwomen, laboring with pneumonia. "So. Mali fix you. Be o-kay."

"How?" I worried. "How can you do that?"

"Many things," she sniffed. Fingering my lips, she commanded, "Open," and compliantly I let her place a grainy crystal nugget on my melting tongue. The stuff dribbled into a coarse, tart syrup which she washed down my throat with a dizzying drink. "Good buoy. May swit buoy," and her long ebony fingers felt mercifully cool as she held my face in her hand.

After that brief stroll on the beach, I sweltered through several days and nights of delirium which are impossible to detail. Engulfed in perdition. Hardly a hero, I was more like a lost soul worming my way across parched sands, splashing through burning grass--yearning only for cool water and crying out for the scorching heat to cease. I would have done anything, anything for relief.

Mali was kind. Always close by. Giving me cold water--more precious to me than gold or diamonds--freely, simply out of friendship. A destitute castaway, I had nothing to give in return. But she cared for me as if I were a prince. Incessantly she bathed my burnt skin in sooting oils and water; something in it would numb my pain and let me sleep. If I gagged on virulent green tentacles of phlegm, Mali braced my forehead and my convulsing bones; when I could breathe again, she gently washed my ruddy face, then lay back down beside me, with night looming all around her cozy hut. Often her sleeping arm embraced me, and even that satin touch seared me like a torturous firebrand, but if it wrung only a wince from me and she did not stir, then soon her long arm felt like lacquered ebony, cool and gleaming, absorbing my terrible heat.

Certainly I know that Aunt Clara, and the rest of our Yankee clan, must be scandalized should they ever read that I slept with a black island woman. But I was so deathly ill that sleeping is all we did. Hale and healthy, brimming with life, Uhuru-Mali had seen neither man nor youth for 17 years, and (as she later told me) more than once she felt inclined to devour me in an orgy of passion. But she was too much of a lady to exploit my hellish delirium.

Hideous nightmares did come leaping at me out of the darkness, like moray eels lunging from black crevices. Dreams of prowling U-boats. My tramp freighter erupting at sea. Drowning women. And a circle of bejeweled demons, surrounding my roasting body.

Terrible, wrathful eyes blinked at me from beneath a crown of frail silver chains and black pearls. A shedevil. I heard my own strangled groan as she clawed my shoulder with a sadistic fork. Demonic fingers twisted my arms tightly as I swirled in a glowing red kettle, with cooking-water boiling above my ears like swarming voices. And my swimming vision saw eyes, many eyes glittering in dark faces. Watching me cook.

"Christian," one of them murmured, condescending to me. "Do you see Mali? Mali be here; I do not liv you." I still felt myself floating like a boiling chicken, but blinking through my acrid tears, I could see her warm smile in the flickering light.

Desperately my eyes clung to her face, maybe the last sweet, living thing I would see. I knew precious little of my Bible, and if God is everywhere, he was always mighty quiet in my neighborhood. So I had no real hope for myself. "Mali," I quavered, certain of damnation, "has the Devil come? Has the Devil come for me?" 


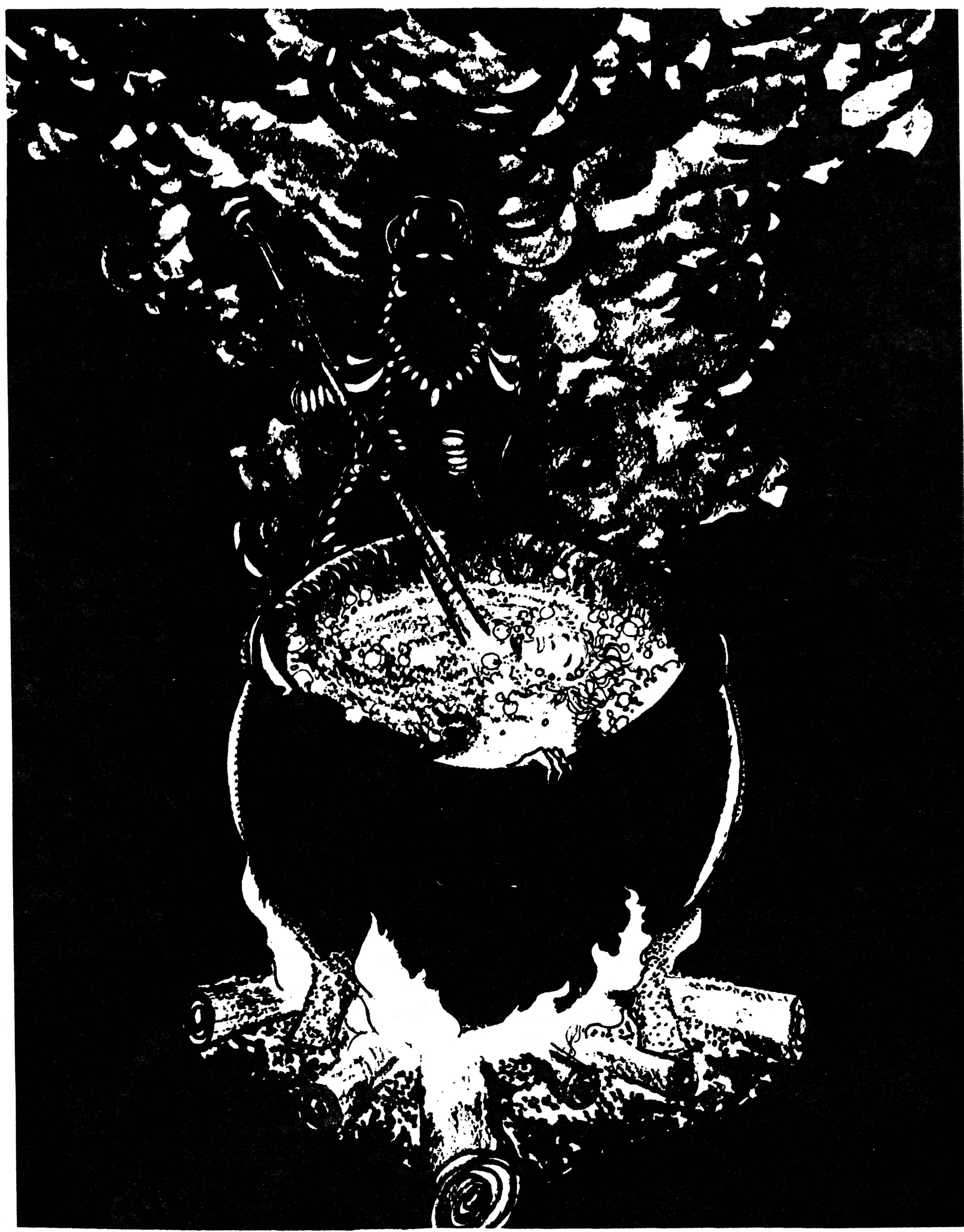


"No, may swit buoy," she chuckled softly, and kindly. "No Devil. No death. This be my sister Marza." Staring dreadfully at her sister's grim visage, I felt that I was looking up at a feminine Mars, a warrior goddess. "Marza has bring many sisters and daughters, many many, to see you."

"Oh," I whispered, and gasped with torment as a fiery claw crackled on my arm again. Watching me with cruel suspicious eyes, Marza shot a torrent of Swahili dialect to her sister, and Mali answered in an easy tone, gesturing mildly over my legs, and then my chest. Cautiously Marza caressed the cooler skin of my pale leg, and then felt the outraged scarlet of my arm. Mali intoned to me, "Marza say, why you be many colors? I say you be white and gold, and sun hava burn you red."

At last my swimming eyes made sense of my surroundings. We were outside the hut, under a starry grove, crowded with a curious circle of island women. Clad in dark linen, leather, and glittering chains and bracelets. Their excited voices effervesced like the broth of a cooking pot. Slender young girls, rather frightened I think, held my arms and legs to the velvet mossy ground. Later I learned that inside the hut, the imperious Marza had uncovered me for a full inspection, but then she securely restored my linen honor before bearing me out to her sisters. Yes, she could confirm, he is a man. Apparently she knew something about basic anatomy.

Even groggy with Mali's drugs, I sensed that most of the tall, powerful women--although armed with fierce lances and long bright knives--were not as frightened as the girls, or as angry as Marza. Her eyes were razored slits as she hissed in Swahili, brazenly accusing her sister of incomprehensible felonies Ripping the air with a knife-like finger to point at me, jingling her silver regalia as she stamped in rage and spit her indictments. Unholy treason. Taboo. Only for a man-child? for this? Clutching her own pelvis with obvious significance.

And when Marza paused, another tall handsome woman piped up with a swift retort, and the whole crowd burst into ecstatic laughter. Marza wilted, incredulous. With twinkling eyes, Mali smiled gratefully at her wiseacre sister; I guessed (correctly) that this one had said, "Could you find a better reason?"

With coaxing, Marza knelt beside these two. Holding her silver chains aside, she bent low to my chest to "hear breath." In Mali's hand, Marza's fingers felt the heat of my glowing face, and Marza looked frustrated, indecisive. Her razored eyes seemed to mellow as the other women knelt beside me too, to murmur their pretty names to me--too many names to remember, in my red haze. "Poor Christian," one would tell Marza in stilted English, and another observed, "His burn red; will you et him, Marza?", with soft ripples of laughter. "His cook too much, not good dinna." And they laughed again, pleasantly.

Taught by Mali, the lady Wise-Acre was delicately rinsing my overcooked skin with water and oil. "I be Havail," she smiled reassuringly. "They hava tiz you, Christian. These cackle women, should they be care for you too? Think so?"

With her lips pursed, Marza looked less like the Grim Reaper, and more like her tender-hearted sisters. "Yes," she pondered hesitantly. "Yes we shoulda do." Daubing my damp face with a swath of her own silk. Mali had told her that their beloved sister Dhao had drowned in the lagoon while trying to save my petti-coated missionary girl, Miss Evangeline Stone, and now Marza decided, "Dhao be with Khandazi, but Mali save you. So. Blue Island women musta care you o-kay. May swit boy."

Doubt still wrinkled her forehead beneath the silver-stranded crown, but Marza's eyes and cruel mouth looked more tranquil. Peaceable.

"His justa poor buoy," Mali told her, and fingered my hair. "Even Christ hava forgot him." 
Marza retorted tartly in her own swift tongue--arrows too quick for me to follow--but I'm sure she said something like: "This poor boy will be trouble! Terrible trouble." Nevertheless, she murmured in English, "Poor Christian," looking down at me, and again, her eyes looked honest to me.

As I drifted in and out of a fevered stupor, I sensed motion. Hardy island women were carrying my cushioned stretcher through a forest of looming trees and luminous stars. At least once, they stopped when I gagged up a fistful of blood. The tall warrior women looked apprehensive about that, but sharing intimate counsel under a looming hedge, Mali and Marza decided that we must keep moving. Royal power shone in their eyes most opulently, and their princely sisters listened to them. As we moved onward, these two walked on either side of my mobile bed. Shivering under a blanket, I could raise my heavy eyelids and see them, watching me. Their presence was comforting to me.

I could not recognize that during Lloki's bloody uprising 17 years ago, Marza had gleefully mutilated and murdered men, just for being men, again and again, and again. The first moment she glimpsed me, her wicked knife flashed searchingly over my soul--saved by the loving-kindness of her sister, Uhuru-Mali, whose powerful arms and soft pleading voice quelled a wild, seething bloodlust, at least for tonight.

I had no hint of that desperate, writhing wrestling match. Right now, Mali told me only that we were climbing to a larger encampment, a better place. "Must be quiet, Christian, 0-kay? Like my sisters, o-kay?" Indeed, they were wisping through the grass like ghosts.

"Has Lloki come?" I asked hoarsely, as Mali daubed flecks of blood from my mouth. "Are there boats on the beach?"

"No. No boat. But must not tell goddess Khandazi that you be here," watching the magic trees apprehensively as she walked. "Snake-goddess maybe send Lloki."

Lloki was the wrath of the goddess. But apparently this goddess was not omniscient. Khandazinambi, "Queen of the gods," was revered as the chief deity of these islands, and of the surrounding seas. Other legendary hints placed "dinambi," other mighty gods, slumbering over in the vast heartland of the African continent. Perhaps even the Supreme God, the Creator, was there. However, enthroned far away in the remotest regions, these virile gods had forgotten the queenly Islands of Women. In a similar way, the women here felt that their own Snake-goddess might not hear of me--as long as our conspiratorial procession spoke of me only in hushed tones. All around us, the birds and frogs and rodents and fish would never speak to their feared and hated enemies, the reptilian kinds; what the women feared was that a curious snake or an eel might call a spirit down to peer at me through the veil of the trees. And then Khandazi would know; A man-child had come to her sacred isle. Breaking taboo.

So we all slipped clandestinely through the misting hillsides, with dim lamps and glinting jewels and blades. If we could make it to a forest village, incorporated under the insignia of an island Queen, then the customary rituals would show the spirits and their messengers a normal appearance. Except at festival times, the gods were not invited under the roofs of the timbered lodges--that was the domain of the women--so they felt that our secret would be safe there. My survival. If I lived.

I wasn't sure I would make it. Incessant heat curled off my skin like smoke in the night air; I always felt that heat, and yet half the time I quivered with cold chills too. Exhaustion weighed on me like lead, but intermittently my lungs bawled like a horse in quicksand--trying to clear a way to breathe. I always did. Swaying, gently, gently in the sturdy stretcher, with two Queens caring for me. Our journey just seemed interminable. Swaying, swaying. I still had that same rhythmic sensation and I was sure we were still walking, when I raised my head from a canopied bed in a solid cozy house, with a flickering fireplace and chimney. "Oh!" I croaked, 
"did, are we, d-did we stop?" After Mali's woven hut, this grand domicile felt alien, strangely European or British. "Are we home?"

"Yes, lil' one," Mali reassured me sleepily, as her hand caressed my face, to feel how hot. "This be Queens' lodge, in stronghold village. Very safe." Rubbing my eyes, I could see that many warrior women were sleeping quietly here, nestled in several alcoves arching around the main boudoir. And the house felt more massive than this. In a soft red robe, Princess Wise-Acre was tending the hearth across the room, and she glanced back at the murmur of voices. Picking up a clinking basket of medicines, Wise-Acre smiled over, and sat down on the perfumed bed. I remember that the filigree on the silver spoons looked very English or Irish to me.

"Well Christian! You hava wake up! You remember me? I be Havail, remember?"

"Yes. Did we just arrive, here?"

"In village? You come here three nights ago, swit buoy. You, in three days you hava not open eyes, till now. You see, why Mali weep for joy?"

Looking to my right, I could see that Mali's pretty face blazed with tears, and her elegant fingers tripped from her lips, laughing and crying, to touch mine.

Havail asked me, "Feel well, Christian?"

"I'm good, I feel fine," and the two Queens laughed softly, just on my right. Looking over dizzily, I saw Mali, weary and relieved, resting on a long feather pillow, and Marza, propped on a polished elbow, with Mali between us. Marza still did not fully trust me, even half-dead. At least she was smiling. "I'm, I'm just a little cold," I chattered.

Reaching across her sister's shoulders--very comely, bare black, ribboned by a crimson halter--Marza reached across to feel my face and neck. Clucking, "Poor buoy, you still burn up. You burn up."

Peeling off my sodden night-shirt, washing, and donning a dry one, I didn't feel so clammy, but the ladies were sweetly adamant: I could not leave the lodge, or even step out on the porch. I knew I was too feeble; nevertheless, I felt inordinately disappointed. So they propped me up beside a window, always with a supportive arm under mine.

For three days I had subsisted on bewitching herbs and drugs, spooned into my mouth and coaxed down by a careful nurse. Now an amiable circle of them were cooking up a mild meaty broth in a little black hearthkettle while the rest of the great house slept. Warm aromas faintly revived my hunger as I studied the moonlit portico, with gleaming hardwood pillars and pale bamboo balustrade. Impressive. The sort of statehouse an African monarch might design after visiting London or Washington.

Like sleeping children, other houses nestled under a fortress-like grove of luxuriant boabab trees, and I could discern a bulwark of stone towers and pointed stakes embracing the village. It looked secure. Chimes of wood and metal tingled under tall standards, like tall bayonets above the stockade; the royal insignia on top were too indistinct for me to see. However, one chilling detail I could see on the exalted porch was the jawless grin of polished skulls, clustered around the feet of each throne. No mandibles. Just bony crowns, with the eyeless stare of death.

"Whose skulls are those?" I asked, trying to keep my voice steady. "Those head-bones, around all the pedestals?"

"Those heads, they worry you?" Sly Marza simpered down at me with veiled eyes.

"Maybe." 
"They be dead," she observed casually, "No magic. Dead enemies, enemies of the Queens. They try to punish Queens, take our crowns. But we take their crowns. I kill many. Many men." Her transfixed eyes were looking back at the Before-time, and her serpentine lips curled contemptuously at how easy it was to murder men, in bed, in water, or spread out under a luxuriant boabab tree. "Giant men. Sometimes I kill alone, and bring back his head; sometimes many women sink one fool in sea or in swamp. Always, every man think we want him."

"I guess you did."

Simpering slyly again, Marza squeezed me with her lithe black arm, and chuckled, coming out of her fatal reverie. Marza was more slender than her half-sister, Mali, but still stronger than me on my best day. Really for the first time in my life, I felt diminutive and vulnerable; I had never known women of such Amazonian stature and strength. And deadly intent. "Bad men, Christian. Lloki lead us and we kill them. Then Lloki say, kingship or queenship always rest on bones of killed ones. On heads of enemies. The king, never he say so. But Queens of Lloki, Queen of queens, we sit on the heads, like a sign for all time. Always remember."

Almost involuntarily I asked, "Are you, will you kill me too, and then put my skull out on the Porch of Thrones?"

"Why shoulda do?" She feigned surprise, "I thought you be good buoy!"

"We're all the same," I blurted, instantly wishing I had not said it, with a muted echo, "the same."

Marza's eyes widened with genuine surprise, and she made my heart jump with a sharp burst of laughter. But her long fingers, without a knife I think, rubbed my back reassuringly. "Maybe," she mulled, "maybe you be diff'rent, little bit," watching me with the twinkling eyes of an amused murderess.

"What happened," I inquired with a horrible fascination, "what did you do with the rest of them?"

"The rest?"

"The corpses. The rest of the bodies."

Mali and Havail glimpsed us curiously as Marza conducted me down an interior hall. They seemed unconcerned as we disappeared, but shuffling into a dark, musty dungeon deep in the palace, I broke out in a cold sweat, and my black widow felt my bones stiffen against her. "O-kay, o-kay," she whispered serenely, pulling me forward.

"Marza," my voice shook, breathlessly, "can we go back, to the main room, please?"

"Marza canno hurt you, my swit buoy," as her cobra-like face glimmered in the light from her delicate oillamp. "Woulda break Mali's heart. She love Dhao so much, and now Mali need you." My head shook so badly that I could hardly hold it up. Clinging to the rim of a black iron kettle which materialized out of the dark, I almost passed-out when Marza kissed my face, smothering with fear, dead certain that instantly she would crush my throat, or slash me open from pelvis to heart.

Instead I heard the clink of pottery, and in the dim cellar, the spider-woman presented a treasured vase, yawning at me with deeper darkness. "Reach in," she commanded, with the scent of cured leather in the air. My trembling hand pulled out a fuzzy scraggle, tightly curled like dark goat's hair, attached to an asymmetrical handball--black-stitched, and oddly condensed. "You see? Men." With his mouth and eyes sewn shut, the shrunken head howled silently at me, and as though hit by lightning, I dropped him into the huge black cooking pot, with a prune-like thud. The cooking pot which had boiled the rest of him, his writhing, meaty corpse, for a cannibalistic banquet, the ultimate rite of brutal usurpation. Surely that was an orgy of celebration where the Snake-goddess herself had come down. 
Pondering the date of her next festival, I slid down the glazed black skin of the huge kettle; with knees on the cold flagstones and my forehead cradled in Marza's gourmet fingers, I tried to throw-up, but I had eaten nothing for three days. So I puked only fear, and flecks of blood from my lungs.

Back up in the rosy warmth of the canopied bed, Marza seemed almost loving now that she had struck me with the terror of Queensland. With her bare arm snaked under my shoulders, she murmured, "You hava see enough tonight? Mm?"

"I think so," nodding numbly. Mali and Havail were ladling their mild, inviting broth and soft squares of bread into porcelain bowls (marked "Sheffield, England" underneath). Their little black kettle, bubbling in the hearth, looked so friendly.

Marza asked me, "Feel hungry now, Christian?"

"I dunno, I, feel a little sick."

With perfect understanding, Mali knelt down beside me too, and Harvail curled up at the foot of the bed. I was surrounded by Queens. Mali observed reproachfully, "My cruel sister hava not wait to frighten may swit buoy. Stop heart. I know she do this, soon or later."

"Yes I do," Marza simpered foxily. Kissing my hand, a subtle lick of her tongue tasted my scarlet skin too. Marza like to play head-games.

"Very cruel, Marza," Havail added quietly, handing her a bowl of wafting stew.

"Yes," Marza agreed, but not penitently. Bemused.

My whole soul was so exhausted, I could only take a little food--and that, only because the three Queens gently urged me to eat something with them. Mali's pretty smile was pensive as she watched my eyes wander from her face to the steaming kettle, and back again. But it was nice and homey. They sat with me while Mali's reeling drugs coursed through and loosened my tongue, blurting my dread certainty that I would be eaten like Hansel and Gretel; advising them that they would find no dark meat on my bones; complaining, with drunken tears, that I was already over-cooked. "Why does everything happen to me?" I blubbered. "I jump off a torpedoed ammunition ship, and I land in your cooking pot! Christ!"

I thought it grossly unfair that the ladies found my predicament so amusing, but wiping tears of laughter from her cheeks, shining like anthracite, Mali held my golden cheeks in her regal hands. Tenderly kissing my forehead. Her appled breath tickled my neck and ear as she murmured memories and promises to me.

"Swit Christian, May swit lil' brother. Mali save you, but not for cooking pot. Mali love you, may swit-heart. In Before-time, we all follow Lloki and kill kings, kill all men. Hate men, stupid men."

"We're all the same," I muttered hopelessly.

"No-no, may swit buoy, no! And anyway, Mali hava kill and et my fill of men. Now, I think maybe the rest of men hava betta use," and I heard Havail and Marza laughing and whispering about that. "I save you, for always. Always keep you safe. O-kay?"

Almost asleep again, I nodded. "O-kay," Mali smiled, and night fell softly around me. 


\section{CUMULUS}

\section{by Russell (Rusty) Wagoner}

I sit alone on the ground

Staring at the clouds;

When focused upon them

There is not a sound

It's always best in the morning

When it's clear and cool;

You lie there on a blanket

And think nothing of the World

A cup of coffee I hold in my hand

In an open field of wonder;

Some people say it is their land

But the bullets are hard to ignore

I lie there covered in bed

My organs have been pierced by lead;

No one shows up, they probably don't care

But I'm still in peace, the clouds are still there 


\section{LIFE}

by Matthew D. Cutlip

Life is a great mystery,

Why are we here

Where are we going

What does the future hold

Perhaps it holds...ETERNITY. 
